(2019), 1 (2): 46-52

\title{
ENGLISH PRONUNCIATION ERRORS BY SUNDANESE SPEAKERS
}

\author{
Dwi Warry Octaviana \\ Institut Pendidikan Indonesia (IPI) Garut \\ dwiwarry@gmail.com
}

\begin{abstract}
The students' first language (Sundanese) often interferes with English pronunciation. For example, the students get difficulties to distinguish in pronouncing certain sounds of vowels such as between /e/ in 'beg' and /æ/ in 'bag', /ei/ in 'wait' and /e/ in 'wet'. Sometimes, the students will be able to identify specific problem sounds and sometimes they will not. Another challenge resulting from differences in the first language is the inability to hear certain English sounds that the students' native language does not contain. Therefore, the study was aimed at finding out the main factors that cause the students' English pronunciation errors and identifying the types of the students' English pronunciation errors. In acquiring the data, the research used descriptive method. The data needed are gained through a sample consisting 10 of 32 students. The sample was randomly selected. The students were given ten items of questionnaire asking for their responses in line with the causes of their English pronunciation errors. Then, the students' English pronunciation errors were found from the analysis of the reading material that had been read by the students. In relation to the data gained, the data findings showed that the main factors that caused the students' English pronunciation errors were coming from internal factors (lack of practice, lack of selfconfidence, and lack of exposure) and from the external factors (the differences in pronunciation between the students' first language (Sundanese) and their target language (English) and the differences between what the correct pronunciation that should be pronounced and its writing actually). After the investigation, the types of English pronunciation errors made by the students in vowels sound were: long and short vowels, diphthongs, and triphthongs. It was caused by the inability to hear certain English sounds that the students' native language does not contain.
\end{abstract}

Keywords: Errors, Interference, Pronunciation

(CPendidikan Bahasa Inggris FPISH IKIP BU Malang

\section{INTRODUCTION}

Language is a means of communication between individuals. It also brings them into relationship with their environment. Therefore, it is socially learned behavior, a skill that is acquired as we grow up in society.In language acquisition, there are several phases where the people can acquire the first language, in the early months of birth. Actually, there would not be significant difficulties in acquiring first language acquisition because its characteristics are subconscious, free learning situation (spontaneous oral conversation), automatic and occur to children (before puberty).

Along with the increasing of the children's age and knowledge, hence, they could not statically stay only in their first language acquisition. Now, they are ready to acquire the second language acquisition or second language learning. Generally, the second language acquisition refers to foreign language teaching-learning process or second language. In the second language acquisition, the people consciously acquire the language, monitored, structured learning situation, and also controlled.

Since Indonesia is a developing country, students must learn English if they want to compete in this globalization era. By the time English becomes an international language, much information and technology will be transferred in English. There are many aspects that must be noticed in learning English. One of them is phonology, the study of speech sounds. 
It is known that Indonesia is multiethnical. Automatically, it has many different tribal languages. Therefore, in learning English pronunciation it will be influenced by the first language. From many tribal languages in Indonesia country, Sundanese is choosen as the subject of research. The phenomenon makes the researcher curious to analyze how far the Sundanese-speaking people first language's influences them in learning English as a second language.

Pronunciation is definitely the biggest thing that people notice when the students are speaking English. Good pronunciation should be one of the first things that the students learn in English. The students can live without advanced vocabulary because they can use simple words to say what they want to say. Besides that, the students can live without advanced grammar because they can use simple grammar structures instead. But, there is no such thing as simple pronunciation. If they do not have good pronunciation, they have bad pronunciation. And the results of bad pronunciation are tragic. Even if they use great vocabulary and grammar, people may simply not understand what they want to say.

The good news is that the students can work on their pronunciation until they speak. For example, the students can learn the sounds of English, listen to recordings, watch English-language television, etc. But first the teachers have to realize that there is a problem! Most English learners do not. This problem can be predicted that they have several problems such as transfer negative from their mother tongue, lack of practice in speaking English, and the like. Clearly, the native language will be the most factors affecting a learner's pronunciation (Brown, 1994:260).

So, the students' first language often interferes with English pronunciation.
For example, when the students pronounce 'seat /si:t/' without tip of the tongue touching lower teeth, middle tongue pressing against hard palate, and sides of tongue against upper teeth, we may hear 'sit /sit/' instead. Based on the statement earlier, the main problems of this investigation are what are the main factors that cause the students' English pronunciation errors? And what types of English pronunciation errors are made by the students?. Therefore, the purposes of the study are as follows: 1 . to know the main factors that cause the students' English pronunciation errors. 2. to identify the types of the students' English pronunciation errors.

Pronunciation is definitely the biggest thing that people notice when the students are speaking English. It plays important role in communication. Due to its importance, pronunciation has been the focus of teaching and learning process. Also, it is one of the teachers' primary concerns because mispronunciation may lead to misunderstanding.

Most of students face some difficulties in pronouncing certain English vowels such as bat /bæt/, burn /b3:n/, arrow /'ærəv/, etc. These are some of the main areas of contrast between the students' native language and target language and what difficulties students have. The majority of English words follow a number of complicated pronunciation rules. Particularly, this study more focuses on English vowel. Here is the distinctions between English and Sundanese vowels.

\section{The Distinctions between English and Sundanese Vowels}

O’Connor cites in his book entitled Better English Pronunciation that vowels are made by voiced air passing through different mouth-shapes; the differences in the shape of the mouth are caused by different positions of the 
tongue and of the lips (p.79). Furthermore, Boey (1975:16) explains that vowels are those segments of speech produced without any interruption or stoppage of the airstream. All vowels are produced with vibration of the vocal cords. Since vowels are produced with free passage of the airstream, they are less easy to describe and classify than consonants. Vowels are sounds in which there is no obstruction to the flow of air as it passes from the larynx to the lips (Roarch, 1983:10; Mi-Lim, 2001).

According to those definitions, it can be concluded that the vowels are sound in spoken language, pronounced with an open vocal tract so that there is no build-up of air pressure at any point above the glottis. In other words, it is the sound produced with no constriction in the vocal tract. The English vowels are easy to see and to feel the lip differences, but they are very difficult to see or to feel the tongue differences, and that is why a detailed description of the tongue position for a certain vowel does not really help us to pronounce it well. There are kinds of English vowels, as follows:

\section{Pure Vowels (Monophthongs)}

English has a large number of vowel sounds. The first ones to be examined are short vowels. The symbols for these short vowels are: I (bit, pin), e (bet, men), æ (bat, man), $\Lambda$ (cut, bus), p (loss, cot), $v$ (look, could). Furthermore, other types of English vowel sounds are the five long vowels; these are the vowels which tend to be longer than the short vowels in similar contexts. Thus, we have: i: (beat, mean), 3: (bird, purse), a: (dark, large), o: (board, port), u: (soon, fool) (Roach, 1983:15).

\section{Diphthongs}

O'Connor explains that a diphthong is a glide from one vowel to another, and the whole glide acts like one of the long, simple vowels. In addition, Roach
(1983:19) also explains that diphthongs are sounds which consist of a movement or glide from one vowel to another. In terms of length, diphthongs are like to the long vowels described above. Perhaps the most important thing to remember about all the diphthongs is that the first part is much longer and stronger than the second part. The total number of diphthongs is eight. Thus, we have: b (beard, fierce), eə (wear, fare), və (sure, cure), eI (paid, face), aI (tide, time), oI (void, boy), , u (load, go), au (loud, cow).

\section{Triphthongs}

The most complex English sounds of the vowel type are the triphthongs (Roach, 1983:22). They can be rather difficult to pronounce, and very difficult to recognize. Triphthong is a glide from one vowel to another and then to a third, all produced rapidly and without interruption. The triphthongs can be looked on as being composed of the five closing diphthongs described in the last section, with /a/ added on the end. Thus we get: elə (layer, player), aIə (liar, fire), วІə (loyal, royal), әงə (lower, mower), avo (power, hour).

The views of English vowels have been discussed above. Hereafter, Sundanese vowels are going to be discussed. Sundanese phonology has five pure vowel sounds: a /a/ (artos, money), é /E/ (carogé, husband), i /i/ (imah, house), o / $/$ / (soca, eye), u / $/ /$ (tilu, three), and two neutral vowels; e /a/ (endog, egg), and eu $/ \gamma /$ (eueut, drink) (Kridalaksana, 1983). Because of the differences in phonology aspect between the students' first language and their target language, most of the students have difficulties to have good English pronunciation. A particular sound which does not exist in the first language can therefore pose a difficulty for the second language learners to produce or sometimes to substitute those sounds 
with similar ones in their mother tongue. These sounds include both vowels and consonants. For example, there is no vowel like/æ/, or no such consonants as $/ \Theta /$ in Sundanese. Therefore, the students have trouble first of all in perceiving these sounds, and consequently try to find nearest equivalents to substitute those new sounds. A typical example will be the substitution of / $/$ / for the English $/ \Theta /$ as in the word 'thin', /e/ for the English /æ/ as in the word 'that'.

\section{Errors Analysis}

Error analysts distinguish between errors, which are systematic, and mistakes, which are not (Ellis, 1994:52). By linguistic level, Lyster \& Ranta (1997:278-280; see also Lee, 1990:59; Donald, 2003; Park, 2010:7) distinguish five major categories of errors for classroom error correction. They are as follows: lexical errors (vocabulary), phonological errors (pronunciation), syntactic errors (grammar), interpretive error (misunderstanding of a speaker's intention or meaning), and pragmatic error (failure to apply the rules of conversation). The rationale for the language-learning theory lies within behaviourism, and the belief that learning is a question of habit formation. The behaviourist believed that when a new habit was learned, old habits would have some effect on the learning process (Johnson, 2001; Yule, 2002). Looking at the effects of one habit on learning another is known in psychology as the study of transfer. Two shorts of transfer are important to the language learning:

\section{Positive Transfer}

Language transfer typically refers to the learner's trying to apply rules and forms of the first language into the second language. The term can also include the transfer of features from one additional language to another (such as from a second to a third language), although this is less common. Transfer is an important factor in language learning at all levels. Typically learners begin by transferring sounds (phonetic transfer) and meanings (semantic transfer), as well as various rules including word order and pragmatics. As learners progress and gain more experience with the target language, the role of transfer typically diminishes.

\section{Negative Transfer (Interference)}

Interference occurs when the learners transfer native language habits into the second language. Interference is believed to take place whenever the habit of the native language differ from those of the target language. It is not the first language "getting in the way" of second language skills. Rather, it is the result of the performer "falling back" on old knowledge when he or she has not yet acquired enough of the second language (Ellis, 1994; Zhang \& Yin, 2009).

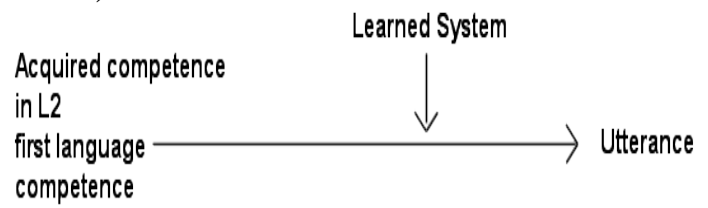

Interference is the result of the use of the first language as an utterance initiator: first language competence may replace acquired second language competence in the performance model above. First language influence may thus be an indicator of low acquisition, or the result of the performer attempting to produce before having acquired enough of the target language. It is, not surprisingly, found most often in foreign language, as opposed to second language situations, where opportunities for real communication are fewer, and is only rarely seen in natural child second language acquisition.

Previous studies have concluded that the learner's first language influences the pronunciation of the target language. 
Also, interference from the first language is likely to cause errors in stress and intonation in the target language. Some Sundanese students tend to have difficulty with English sounds because they are deeply influenced by similar Sundanese sounds.

\section{RESEARCH METHOD}

In acquiring the data, this study used descriptive method. The study used a questionnaire in collecting data that consisted of closed questions. In relation to the type of the objective of this study, questionnaire was given to know the students' responses dealt with their perceptions in learning English pronunciation and also the causes of their English pronunciation errors. Then, the students' responses toward the statements attached in the questionnaire. Then, they were collected, calculated, and analyzed. Next, reading material was administered to the students for identifying the students' English pronunciation errors. Hence, the recorder was used for recording when the sample of this study was reading the material so that the students' English pronunciation errors could be further identified.

The subjects of this study were the students of class XII at one of Senior High Schools in Garut, west java. The total of the subjects were 32 students. Since the subjects were large in number, the study took some of them as a representative sample. The sample was 10 students through random selection. In analyzing data, the form referred to interpretation of the students' responses on questionnaire statements. And then, the later concerned with the calculation of frequency and percentage the result. In detail the techniques of data analysis were as follows: First, analyzing the result or the students' responses. Then, explaining the various responses from the subject of research. After that, classifying the students' responses categorizes. Next, counting the number and percentage of responses. Also, grouping and inserting the students' responses to the tables. The last one, giving the interpretation. These steps of data analysis were purposed to know the students' responses dealt with their perceptions in learning English pronunciation and also the causes of their English pronunciation errors. Furthermore, the reading material that had been read by the sample of the study and also had been recorded was analyzed by the researcher based on the transcription of phonetic symbols. Underpinning into Oxford Learner's Pocket Dictionary, the types of the students' English pronunciation errors in English vowels could be identified.

\section{DISCUSSION}

The main factors that cause the students' English pronunciation errors are coming from internal and external factors. They have a lot of difficulties in producing the appropriate English pronunciation because they are lack of practice in speaking English. Besides that, they are shy and lack of self confidence when they have a communication in English. Then, they are also lack of exposure in improving their ability in having the appropriate English pronunciation. For example: they listen to the English music and watch the English movie rarely. Meanwhile, the external factors that are the students have difficulties in having good English pronunciation because of the differences between what the correct pronunciation that should be pronounced and its writing actually. Also, it is because of the differences in pronunciation between the students' first language and their target language so that most of the students have difficulties to have good English pronunciation. In other words, another challenge resulting from differences in the first language is 
the inability to hear certain English sounds that the native language does not contain.

The types of the students' English pronunciation errors especially in English vowels could be identified after the students read the material . It shows that there are seven common pronunciation problems made by the students. They are /ə/, /æ/, /っ:/, /eI/, /av/, / ə v/, /avə/. Generally, it is caused because of the differences in pronunciation between the students' first language and their target language so that most of the students have difficulties to have good English pronunciation. In other words, there are certain English sounds that the native language does not contain. Some students pronounce the word with short sound; actually it must be pronounced by long sound. For examples: saw /so:/ becomes /spw/, cream /kri:m/ becomes $/ \mathrm{krim} /$, were /wər/ becomes /weureu/, etc. Also, some students pronounce the word like how to write it down. For example: window /'wIndəu/ becomes /'wIndpw/, video /'vIdIov/ becomes /'vIdIp/, etc. Besides that, the students are not able to produce English triphthongs such as our /'ava/ becomes /'awe(r)/. Here, it means that the students have difficulties in producing English diphthongs and triphthongs because those are English sounds that the students' native language does not contain. So, they are not in having good English pronunciation. After the investigation, the types of English pronunciation errors made by the students in vowels sound are: long and short vowels, diphthongs, and triphthongs.

\section{CONCLUSION}

The internal and external factors mentioned above influencing Sundanese students pronounce English. On the other hand, the presentations of distinctions between Sundanese and
English phonological systems may raise students' awareness of the differences of the two sound systems to avoid errors in pronunciation. Therefore, the second language learners should pay attention of the importance of the English pronunciation learning in order to have good communication in English.

In striving to encounter these problems, the English teachers should be more creative in solving the students' problems in English pronunciation. It can be done by enforcing them to do a lot of speaking practices. Consequently, by doing a lot of practices, the students will have a better skill in producing English sounds. The exercise allows clear practice in production and reception and gives concise feedback to individual learners as to where their problems lie in these areas and how to repair them. The differences in the first language are the inability to hear certain English sounds that the students' native language does not contain. For problems such as this, listening is crucial because students can not produce a sound they can not hear. Descriptions of the sound and mouth position can help students increase their awareness of subtle sound differences. The teachers also should focus on production as the main problem affecting the students. For example: give the students the assignment that relates to English music. Then, they have to listen it carefully and write its lyrics. This practice has purpose so that the students get appropriate pronunciation from what they have listened to the music lyrics.

\section{REFERENCES}

Brown, H.D. (1994). Teaching by Principles. An Interactive Approach to Language Pedagogy. New Jersey: Prentice Hall Regents.

Dalton, David F. (1997). Some Techniques for Teaching 
Pronunciation. Retrieved November 9, 2014, from http://www.aitech.ac.jp/ iteslj/.

The Internet TESL Journal, Vol. III, No. 1, January 2007.

Donald, R. (2003). Error Correction. Retrieved from www.teachingenglish.org.uk/thin k/articles/error-correction-1. February 15, 2015.

Ellis, Rod. (1994). The Study of Second Language Acquisition. New York: Oxford University Press.

Johnson, Keith. (2001). An Introduction to Foreign Language Learning And Teaching. London: Pearson Education.

Lee, N. (1990). Notions of 'Error' and Appropriate Corrective Treatment. Hongkong Papers In Linguistics and Language Teaching 13(1990) ISSN10152058 , p. 55-69. Hongkong: Baptist College.

Lyster, R. \& Ranta, L. (1997). Corrective Feedback and Learner Uptake: Negotiation of Form in Communicative Classrooms. SSLA, 20, 37-66. Cambridge: Cambridge University Press.

Mi-Lim, Ryoo. (2001). Vowel Quality and Consonant Voicing: The Production of English Vowels and Final Stops by Korean Speakers of English. Texas Papers in Foreign Language Education, v6 n1 p133-146 Fall 2001. Retrieved from www.link.aip.org/link/?JASMA N/48/104/1. September 5, 2014.

O'Connor, J.D. Better English Pronunciation. Cambridge: Cambridge University Press.

Oxford Learner's Pocket Dictionary. (1991). Oxford: Oxford University Press.

Park, H. S. (2010). Teachers' and Learners' Preferences for Error Correction. Published Thesis.
Sacramento: California State University.

Yule, G. (2002). The Study of Language. New York: Oxford University Press.

Zhang, F. \& Yin, P. (2009). A Study of Pronunciation Problems of English Learners in China. Asian Social Science Vol. 5, No. 6. p. 141-146. Retrieved May 22, 2015, from www.ccsenet.org/journal.html. 